\title{
THE EAST ANATOLIAN FAULT: GEOMETRY, SEGMENTATION AND JOG CHARACTERISTICS
}

\author{
Tamer Y. Duman* \& Ömer Emre
}

${ }^{1}$ General Directorate of Mineral Research and Exploration (MTA),
Department of Geological Research, 06800, Ankara, Turkey

${ }^{*}$ Corresponding author (e-mail: tduman@mta.gov.tr)

Abbreviated title

EAF: Segmentation and Fault Jog

From: Robertson, A.H.F., Parlak, O. \& Ünlügenç, U.C. (eds) 2012 Geological Development of Anatolia and Eastern Mediterranean Region. Geological Society, London, Special Publications, 372. http://dx.doi.org/10.1144/SP372.14 @ The Geological Society of London 2012. Publishing disclaimer www.geolsoc.org.uk/pub_etihcs 
This electronic supplement is made up of 5 figures including additional annotated field photographs and two data tables.

Typical structural and geomorphological characteristics and long-term offsets of the fault segments of the northern and strands of the EAF zone are given in the figures. The segments and fault jogs names of the EAF zone are compared in the tables.

Most of the literature cited is listed in the bibliography of the published paper; the others are given with this supplementary material.

Electronic Supplementary Publication, Table 1. Comparison of the segment names of the EAF zone. Abbreviations: EP, Eastern part; WP, Western part; F, Fault; S, Segment; G, Gülen et al. (1987); HA, Herece \& Akay (1992); P, Perinçek et al. (1987); PÇ, Perinçek \& Çemen (1990); PE, Perinçek \& Eren (1990); PK, Perinçek \& Kozlu (1984); SA: Seymen \& Aydin (1972); W, Westaway (2003).

\begin{tabular}{|c|c|c|c|c|c|c|c|}
\hline This study & $\begin{array}{l}\text { Different } \\
\text { Researchers }\end{array}$ & $\begin{array}{l}\text { Şaroğlu } \\
\text { et al. (1992a) }\end{array}$ & $\begin{array}{l}\text { Herece } \\
(2008)\end{array}$ & $\begin{array}{l}\text { Westaway } \\
\text { (1994) }\end{array}$ & $\begin{array}{l}\text { Hempton } \\
\text { et al. }(1981)\end{array}$ & $\begin{array}{l}\text { Barka \& } \\
\text { Kadinsky-Cade } \\
(1988)\end{array}$ & $\begin{array}{l}\text { Muehlberger \& } \\
\text { Gordon (1987) }\end{array}$ \\
\hline $\begin{array}{l}\text { Karlıova } \\
\text { Ilıca }\end{array}$ & Bingöl $\mathrm{F}$ by $\mathrm{SA}$ & $\begin{array}{l}\text { Karlıova- } \\
\text { Bingöl S }\end{array}$ & Göynük S & Göynük F & S-1 & FS-1 & S-1 \\
\hline Palu & $\begin{array}{l}\text { Palu-Aydın F by } \\
\text { HA }\end{array}$ & $\begin{array}{l}\text { Palu-Lake } \\
\text { Hazar }\end{array}$ & Palu S. & $\begin{array}{l}\text { Palu- } \\
\text { Hazar F }\end{array}$ & EP of S-3 & FS-4 & EP of $S-3$ \\
\hline Pütürge & $\begin{array}{l}\text { Sivrice-Sincik F } \\
\text { by HA }\end{array}$ & $\begin{array}{l}\text { Lake Hazar- } \\
\text { Sincik S }\end{array}$ & Şiro S & $\begin{array}{l}\text { Hazar- } \\
\text { Şiro F }\end{array}$ & WP of S-3 & FS-5-7 & WP of S-3 \\
\hline Erkenek & --------- & $\begin{array}{l}\text { Çelikhan- } \\
\text { Erkenek S }\end{array}$ & Erkenek S & Göksu F & EP of S-5 & FS-9 & $\mathrm{EP}$ of $\mathrm{S}-5$ \\
\hline Pazarcık & $\begin{array}{l}\text { EP of Gölbaş1- } \\
\text { Osmaniye } S \text { by G }\end{array}$ & $\begin{array}{l}\text { Erkenek- } \\
\text { Türkoğlu S }\end{array}$ & Gölbaşı S & $\begin{array}{l}\text { Gölbaş1- } \\
\text { Türkoğlu F }\end{array}$ & WP of S-5 & FS-11-12 & WP of S-5 \\
\hline Amonos & $\begin{array}{l}\text { Amanos F by PE, } \\
\text { PÇ } \\
\text { Karasu S by G }\end{array}$ & $\begin{array}{l}\text { Türkoğlu- } \\
\text { Antakya S }\end{array}$ & $\begin{array}{l}\text { Islahiye S } \\
\text { Kirikhan S } \\
\text { Hassa S } \\
\end{array}$ & $\begin{array}{l}\text { Karasu } \\
\text { segment } \\
\text { of DSFZ } \\
\end{array}$ & & & \\
\hline Sürgü & Sürgü $F$ by $P K$ & Sürgü F & & & & & \\
\hline Çardak & Göksun F by $\mathrm{P}$ & Elbistan F & & & & & \\
\hline Reyhanlı & ------- & Reyhanl1 F & & & & & \\
\hline Yumurtalık & ------ & Yumurtalık F & & & & & \\
\hline Karataş & ------- & Karataş F & & & & & \\
\hline Yesemek & $\begin{array}{l}\text { East Hatay } \\
\text { FS by W }\end{array}$ & & & & & & \\
\hline Savrun & $\begin{array}{l}\text { Çiçeklidere- } \\
\text { Savrun F by P }\end{array}$ & & & & & & \\
\hline
\end{tabular}


Electronic Supplementary Publication, Table 2. Comparison of the fault jog names of the EAF zone. Abbreviations: A, Aksoy et al. (2007); AŞ, Arpat \& Şaroğlu (1972); BK, Barka \& Kadinsky-Cade (1988); Ç, Çetin et al. (2003); G, Gülen et al. (1987); GM, Garcia Moreno et al. (2011); HA, Herece \& Akay 1992; HE, Herece (2008); H1, Hempton (1980); H2, Hempton (1982); H3, Hempton et al. (1983); HD, Hempton \& Dewey (1981); HDU, Hempton \& Dunne (1984); M, Mann et al. (1983); M1, Mann (2007); McK, McKenzie 1976; MG, Muehlberger \& Gordon 1987; PÇ, Perinçek \& Çemen (1990); Ş, Şaroğlu at al. (1992a); ŞE, Şengör et al. (1985); W, Westaway (1994); WA, Westaway \& Arger (1996).

This study Previous studies

\begin{tabular}{|c|c|c|c|c|}
\hline $\begin{array}{l}\text { Gökdere } \\
\text { restraining bend }\end{array}$ & $\begin{array}{l}\text { Gökdere uplift } \\
\text { by Ş, AŞ, HE }\end{array}$ & $\begin{array}{l}\text { Restraining double bend } \\
\text { by } \mathrm{BK}, \mathrm{G}\end{array}$ & $\begin{array}{l}\text { Restraining bend } \\
\text { by GM, M1, PÇ }\end{array}$ & $\begin{array}{l}\text { Compressional bend } \\
\text { by HD }\end{array}$ \\
\hline $\begin{array}{l}\text { Lake Hazar } \\
\text { releasing bend }\end{array}$ & $\begin{array}{l}\text { Lake-Hazar pull-apart } \\
\text { by Ş, BK, GM, H1, } \\
\text { H2, H3, HDU, M, } \\
\text { ŞE, Ç, HE }\end{array}$ & $\begin{array}{l}\text { Mega Sag } \\
\text { by HD, } \\
\text { Sag-pond } \\
\text { by McK, W }\end{array}$ & $\begin{array}{l}\text { Negative flower } \\
\text { structure by A }\end{array}$ & $\begin{array}{l}\text { Evolved pull-apart basin } \\
\text { by GM }\end{array}$ \\
\hline $\begin{array}{l}\text { Gölbaşı } \\
\text { releasing } \\
\text { stepover }\end{array}$ & $\begin{array}{l}\text { Gölbaşı pull-apart } \\
\text { by Ş, G, }\end{array}$ & $\begin{array}{l}\text { Gölbaşı pull-apart formed } \\
\text { in a triple junction } \\
\text { by WA }\end{array}$ & $\begin{array}{l}\text { Lowlands } \\
\text { by PÇ }\end{array}$ & \\
\hline $\begin{array}{l}\text { Yarpuzlu } \\
\text { restraining } \\
\text { double bend }\end{array}$ & $\begin{array}{l}\text { Restraining bend } \\
\text { by GM, G }\end{array}$ & $\begin{array}{l}\text { Right -stepping bend } \\
\text { by HD }\end{array}$ & $\begin{array}{l}\text { Çelikhan uplift } \\
\text { by HE }\end{array}$ & \\
\hline
\end{tabular}

\section{References}

AksoY, E., İNCEÖZ, M. \& KoçYIĞIT, A. 2007. Lake Hazar Basin: A Negative Flower Structure on the East Anatolian Fault System (EAFS), SE Turkey, Turkish Journal of Earth Sciences, 16, 319-338.

Hempton, M.R., 1980. Structure and morphology of the East Anatolian Transform Fault Zone near Lake Hazar. Geological Society of America Annual Meeting, Abstracts with Programs 12, 445.

Hempton, M.R., DUNNE, L.A. \& DEWEY, J.F. 1983. Sedimentation in an active strike-slip basin, south-eastern Turkey, Journal of Geology, 91, 401-412.

KOZLU, H. 1987. Structural development and stratigraphy of Misis-Andırın region. Proceedings of the $7^{\text {th }}$ Turkish Petroleum Congress of Turkey, 6-10 April 1987, Ankara, Turkey, 104-116.

MANN, P. 2007. Global catalogue, classification and tectonic origins of restraining and releasing bends on active and ancient strike-slip fault systems. In: Cunningham, W. D. \& Mann, P. (eds) Tectonics of strike-slip restraining and releasing bends, Geological Society, London, Special Publications, 290, 13-142. 


\section{Figures}

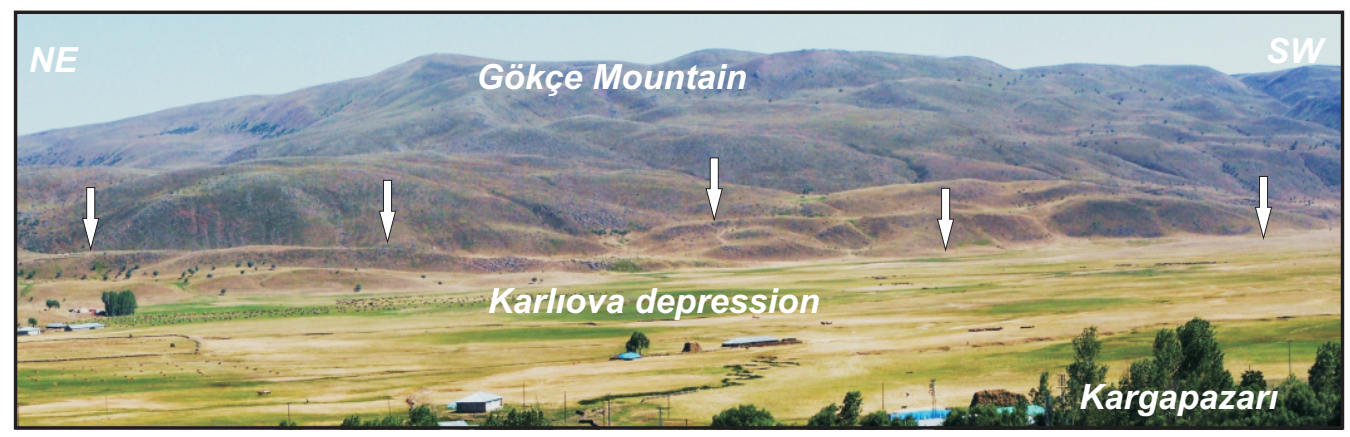

Electronic Supplementary Publication, Fig.1. Fault lineaments and shutter ridges along the Karlıova segment of the East Anatolian Fault at Kargapazarı. 

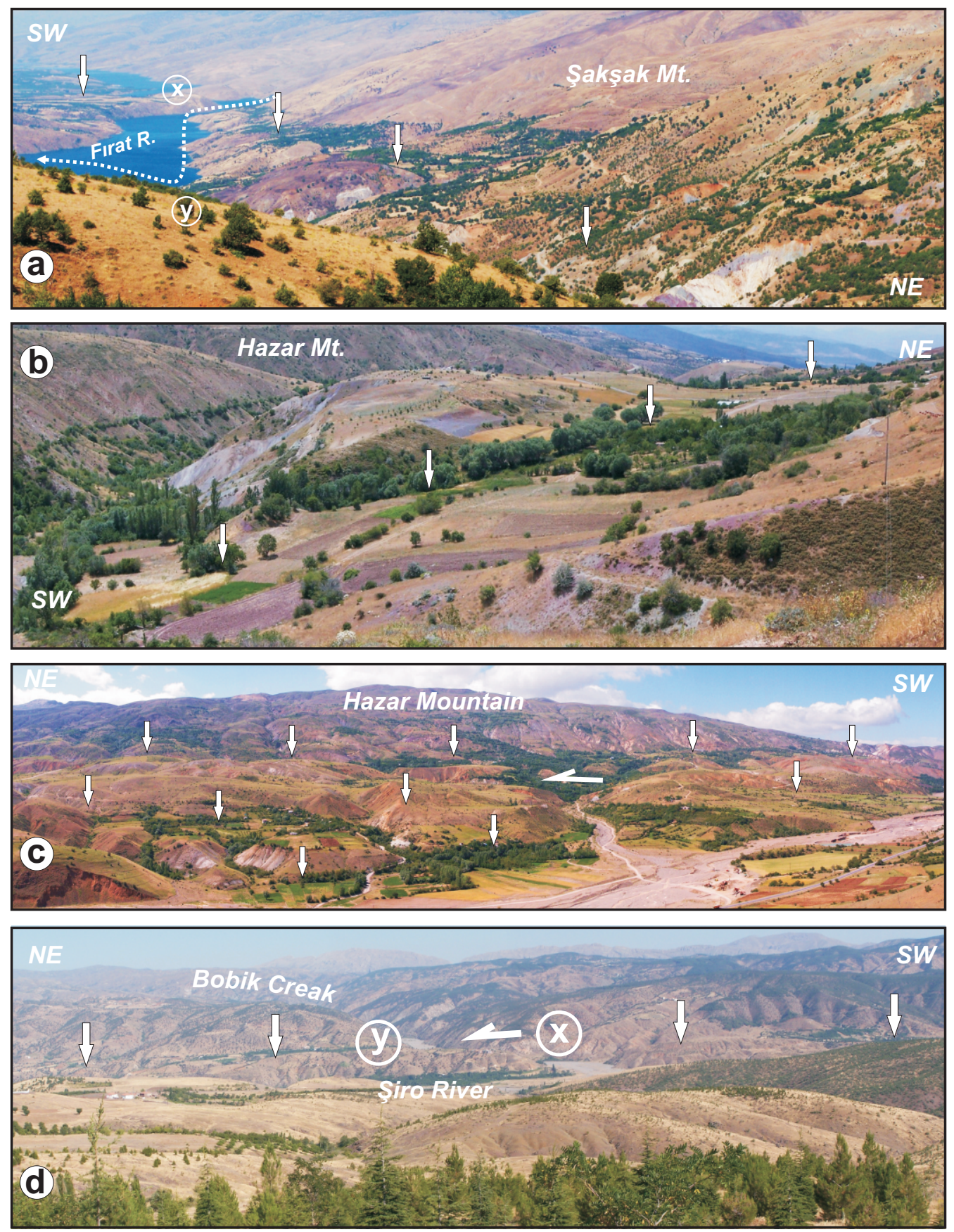

Electronic Supplementary Publication, Fig.2. Typical structural and geomorphological characteristics of the Pütürge segment of the East Anatolian Fault: (a)steep linear mountain front parallel along and the left lateral offset of $11 \mathrm{~km}$ in Frat River around Doğanyol on the Pütürge segment; (b) steep linear mountain front parallel along the Pütürge segment between Kamışlık and Hazar mountains; (c) faults characterised by parallel faults and stepped morphology at the west of the Lake Hazar; (d) left lateral cumulative offset of $c .500 \mathrm{~m}$ in the Bobik River which is tributary of Fırat River; The direction of the photographs is indicated for each photo. " $x$ " and " $y$ " denote piercing points used for slip in photographs. Perpendicular and lateral arrows indicate fault trace and fault slip direction, respectively. 

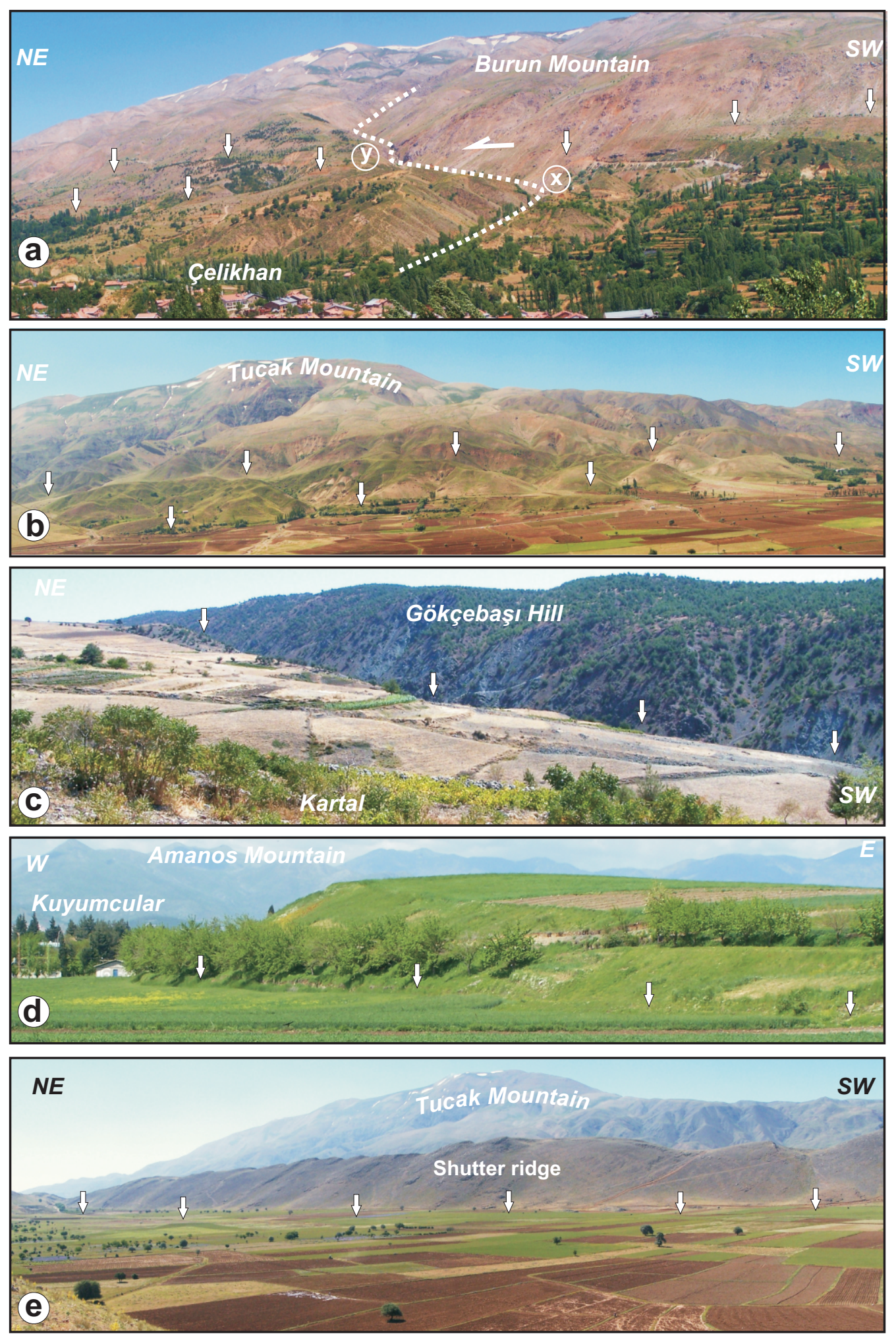

Electronic Supplementary Publication, Fig.3. Typical structural and geomorphological characteristics of the Pütürge, Erkenek and Pazarcık segment of the East Anatolian Fault: (a) offset of c.450m in Şehment creak on the Pütürge segment immediately north of Çelikhan; (b) scarplets, lineaments and shutter ridges in the northern outskirts of the Ulubaba Mountain along the Erkenek segment; (c) linear valley at Kartal on the Pazarcık segment; (d) fresh fault scarps forming a contact between Quaternary deposits and basement rock at Kuyumcular on the Pazarcık segment; (e) a shutter ridges of $c .1 \mathrm{~km}$-wide and $c .17 \mathrm{~km}$-long formed along the Sürgü fault segment. The direction of the photographs is indicated for each photo. " $x$ " and " $y$ " denote piercing points used for slip in photographs. Perpendicular and lateral arrows indicate fault trace and fault slip direction, respectively. 

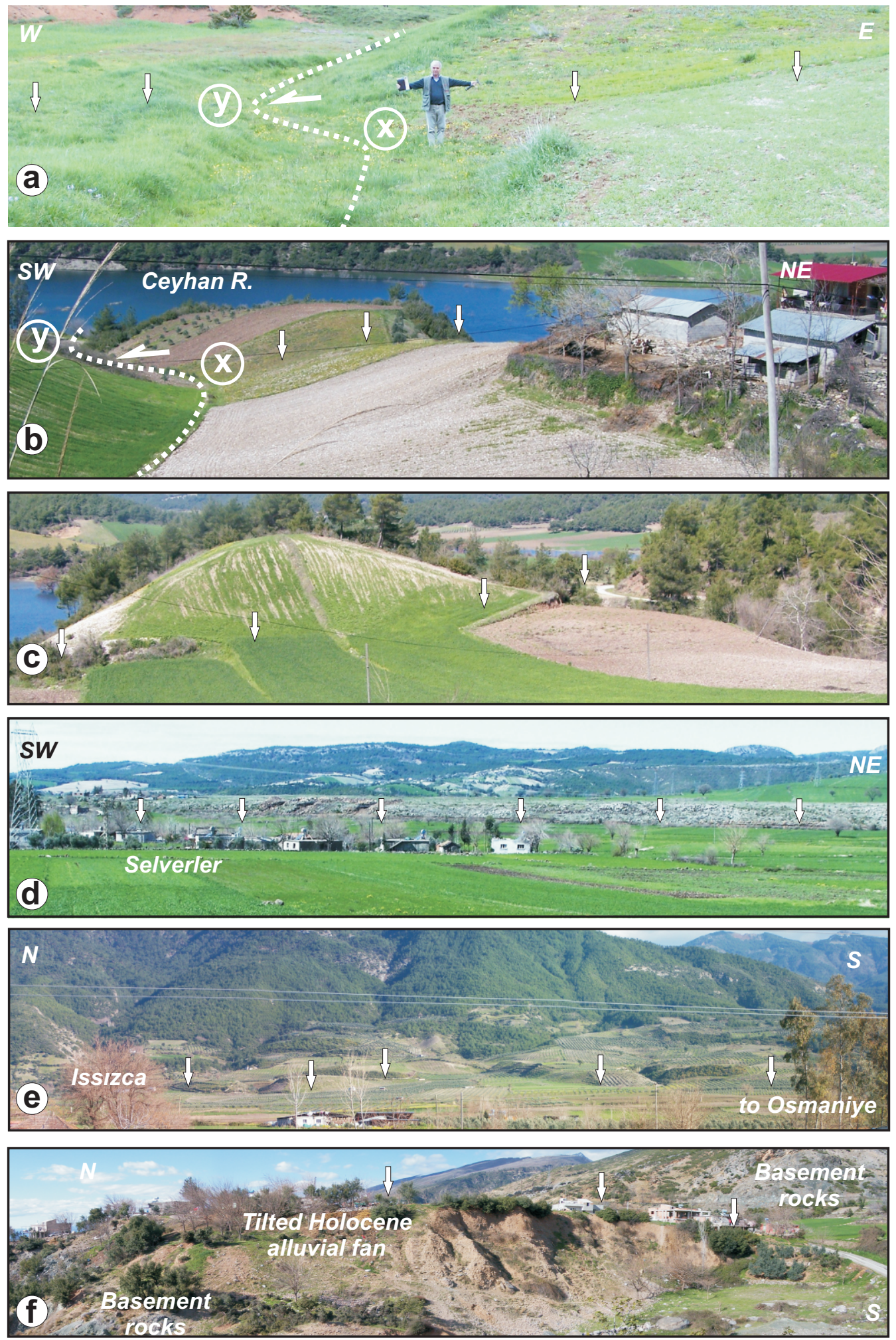

Electronic Supplementary Publication, Fig.4. Typical structural and geomorphological characteristics and short and long term offsets of the northern strand the EAF zone: (a) offset of c.5 $\mathrm{m}$ in a channel at Meryemçilbeli River valley on the Savrun fault segment; (b) left lateral offsets of 20-30 m Holocene tributaries of Ceyhan River, west of Selverler; (c) a shutter ridges was occurred on the Toprakkale fault, west of Selverler; (d) general view of the Toprakkale fault which cut Quaternary basaltic lavas between Selverler and Karagedik; (e) Holocene fault scarps located on the alluvial fans at the mountain foot forming steeped morphology on the Düziçi-Osmaniye segment, immediately north of Osmaniye; (f) back-tilted Holocene alluvial fans formed on the hanging wall block of the Düziçi-Osmaniye segment, immediate north of Düziçi; The direction of the photographs is indicated for each photo. " $\mathrm{x}$ " and " $\mathrm{y}$ " denote piercing points used for slip in photographs. Perpendicular and lateral arrows indicate fault trace and fault slip direction, respectively. 

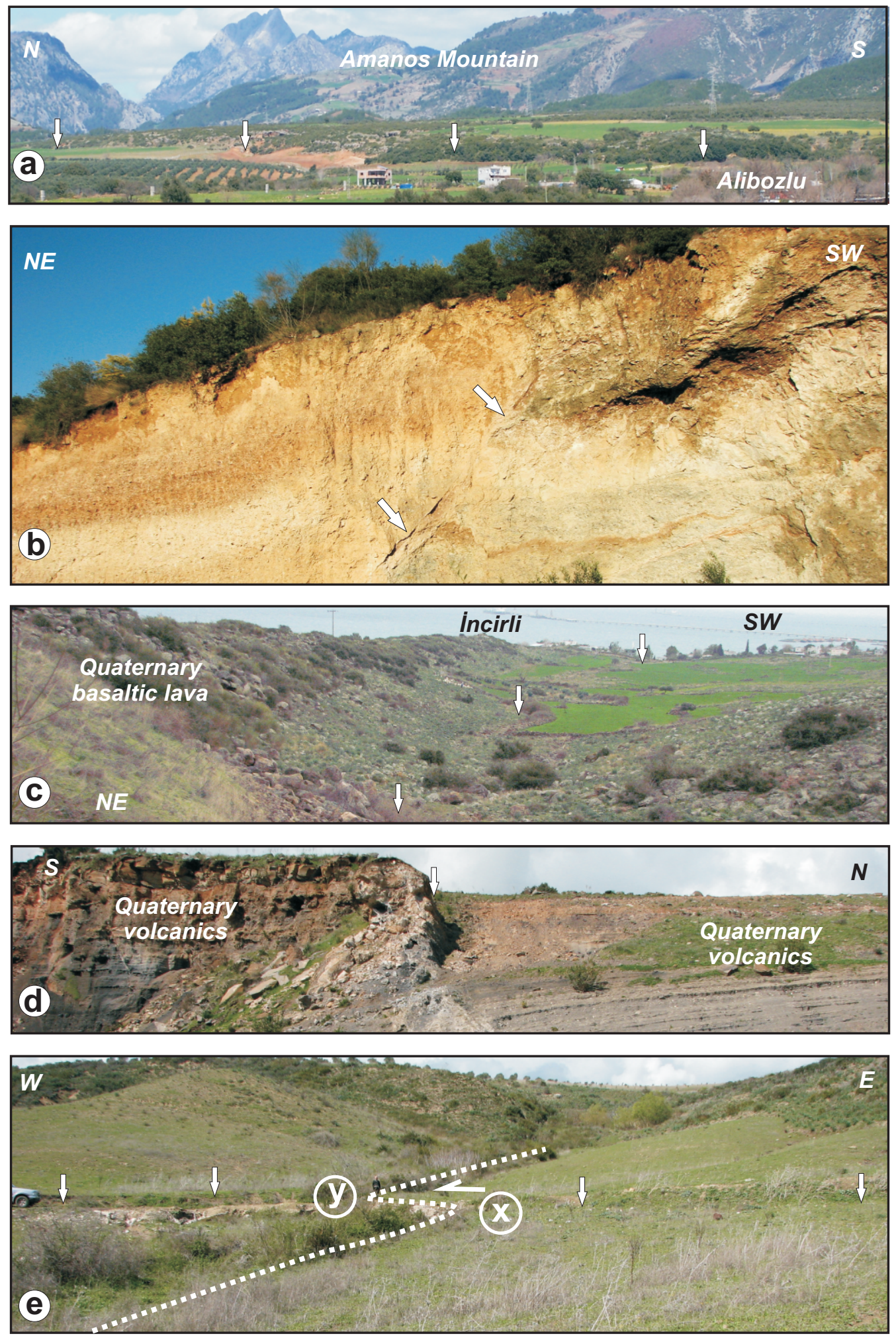

Electronic Supplementary Publication, Fig.5. Typical structural and geomorphological characteristics and short and long term offsets of the northern strand the EAF zone: (a) the fault scarps in Pleistocene fans, reaching up to $4-5 \mathrm{~m}$, between Elbeyli and Alibozlu; (b) fault plane dipping $65^{\circ}$ west in Pleistocene fan deposits crops out to the immediate south of the Yeşiltepe; (c) Holocene fault scarp related to the Yumurtalık fault in Quaternary volcanics, immediate north of İncirli; (d) fault plane of the Yumurtalık fault observed on Quaternary Delihalil volcanics at İncirliKurtkulağı raodcut; (e) a left lateral offset of $8 \mathrm{~m}$ observed in a gully channel on the Yumurtalık fault, north of İncirli. The direction of the photographs is indicated for each photo. " $x$ " and " $y$ " denote piercing points used for slip in photographs. Perpendicular and lateral arrows indicate fault trace and fault slip direction, respectively. 